\title{
GOVERNMENTS, INFORMAL LINKS TO MILITIAS, AND ACCOUNTABILITY*
}

\author{
Sabine C. Carey \\ University of Mannheim \\ Michael P. Colaresi \\ Michigan State University
}

Neil J. Mitchell

University College London

Forthcoming in Journal of Conflict Resolution

From Syria to Sudan, governments have informal ties with militias that use violence against opposition groups and civilians. Building on research that suggests these groups offer governments logistical benefits in civil wars as well as political benefits in the form of reduced liability for violence, we provide the first systematic global analysis of the scale and patterns of these informal linkages. We find over 200 informal state-militia relationships across the globe, within but also outside of civil wars. We illustrate how informal delegation of violence to these

\footnotetext{
* Neil Mitchell and Sabine Carey received funding from the Economic and Social Research Council (ESRC), UK, RES-062-23-0363; Sabine Carey received funding from the FP7 Programme, ERC-StG-2013 no. 336019. The replication data can be found at http://dx.doi.org/10.7910/DVN/28603.
} 
groups can help some governments avoid accountability for violence and repression. Our empirical analysis finds that weak democracies as well as recipients of financial aid from democracies are particularly likely to form informal ties with militias. This relationship is strengthened as the monitoring costs of democratic donors increases. Out-of-sample predictions illustrate the usefulness of our approach that views informal ties to militias as deliberate government strategy to avoid accountability. 
During the Sudan civil war, reports alleged that government helicopter gunships dropped supplies in remote locations, not to supply uniformed government military personnel, but rather the armed gangs of the Janjaweed militia (Vasagar 2004). When questioned about its ties to the Janjaweed after the Darfur atrocities, the government claimed it was disarming not arming the group. ${ }^{1}$ Subsequent testimony from Janjaweed commanders explained the Sudanese government's role in sponsoring and working with the militia in unofficial capacities, despite government denials (Meo 2008). In this article we examine the enduring attraction of armed nonstate actors for governments.

A government clandestinely delivering weapons to groups outside the state security apparatus is at odds with the idea of consolidating a monopoly on violence. Despite the conventional view, there is no necessary process of monopolization (Staniland, forthcoming). Evidence suggests that armed groups, like the Janjaweed, often operate in vague and informal concert with the state. Yet with the exception of Ahram's (2011a) analysis of data from the 1970s, and Bates' (2008) work on state failure in Africa, there is a lack of quantitative research in this area, while there is a rich case study literature for Latin America (Mazzei 2009; Stanley 1996), Indonesia (Cribb 2001), Africa (Alvarez 2006; Kirschke 2000; Roessler 2005), and elsewhere (Campbell and Brenner 2000; Kalyvas 2008; Mitchell 2004).

A new database includes global information from 1981 to 2007 on pro-government militias and defines informal relations between the government and a militia as those "not officially or formally acknowledged" by the government (Mitchell and Carey 2013, 11). There are 218 of

\footnotetext{
1 “The Darfur Crisis: Sudan's Janjaweed Militia” PBS NewsHour, April 7, 2006, available online at http://www.pbs.org/newshour/indepth_coverage/africa/darfur/militia.html.
} 
these relationships in over 60 countries (Carey, Mitchell and Lowe 2013). ${ }^{2}$ Militia-government cooperation is most likely in, but not limited to episodes of armed conflict, as $42 \%$ of our country-year observations with informal PGMs occur outside of armed conflict, using the threshold of 25 battle-related deaths (Gleditsch et al. 2002). These informal links can be found in a heterogeneous group of countries around the globe. They are present in poor states, such as Sudan and Haiti, and more developed states, such as South Africa and Chile, as well as in autocracies such as Zimbabwe and Burma, and in more democratic India, Spain, and Turkey.

Why delegate violence to armed groups instead of using the official security apparatus? Why supply the Janjaweed when the Sudanese military itself lacked supplies? ${ }^{3}$ We identify logistical and political incentives for governments to informally collaborate with militias despite - and because of - the limited control they have over them (see also Jentzsch, Kalyvas, and Schubiger, forthcoming). As low cost force multipliers and with likely information advantages in insurgencies, there are logistical incentives to use these groups. Eck (forthcoming), using a finegrained sub-national analysis, explains delegation to militias as compensation for intelligence disruptions conditional on military purges and civil war threat. In addition, such delegation carries the political benefit of shifting responsibility (Fiorina 1985). Building on research on the influence of accountability on government repression (e.g. Landman 2005; Simmons 2009) and the case literature (e.g., Alvarez 1996; Kirschke 2000; Roessler 2005), we explain militias as an option for evading the accountability costs facing governments that are clearly responsible for official violence. If governments are sensitive to accountability costs attached to repression,

\footnotetext{
${ }^{2}$ These groups are common but not found in every country for there are costs to delegation and uncertainty about whether the task, in our case regime security, will be delivered (e.g., Mitnick 1980). Williamson highlights the hazard of contracting "sovereign transactions" $(1999,320)$ and incomplete control "can also invite the private provider to distort the mission to meet its own preference rather than those of the broad public" (Donahue and Zeckhauser 2011, 32). Governments likely consider the damage to reputation and the longer-term reliability of informal groups, including the prospect of betrayal.

${ }^{3}$ See "Country Profile: Sudan", Library of Congress, December 2004, pg. 14, available at http://memory.loc.gov/frd/cs/profiles/Sudan.pdf
} 
unofficial links to militias offer a means to shift responsibility for violence: "these forces tend to be more 'deniable' and opaque than formal government security forces, allowing the state to avoid accountability" (Staniland 2012, 17). Beyond providing force, informational and deployment advantages to governments under the threat of civil violence, militias mitigate the risk of domestic and international liability for repression. ${ }^{4}$ After presenting the argument and some case examples, we move to the empirical analysis. Our results are consistent with the expectation that these linkages are a response to armed conflict and disorder. But beyond this disorder explanation, the results also support the argument that unofficial government-militia cooperation reflects strategic choices to reduce governments' liability for repression.

\section{Militias and Accountability}

We assume governments may perceive important strategic benefits from the use of violence, if they can lower the perceived costs associated with its use. We know that even democratic governments are willing to violate human rights for strategic benefits, such as shifting unwanted civilian populations or ending a costly war and violent dissent (Downes 2006; Conrad and Moore 2010). Rather than forego repression, governments may instead seek to evade accountability for it.

We argue that governments perceive ties to militias as a mechanism to evade accountability and muddy the flow of information about who is responsible for violence. Recent work has shown that militias increase the risk of state-sponsored repression (Mitchell, Carey, and Butler 2014). Accountability has two major components: information and conditional sanctions

\footnotetext{
${ }^{4}$ These incentives fit Donahue and Zeckhauser's (2011) production, information, and legitimacy motivations to delegate policy tasks to private actors, therefore uniting the security sector with other policy domains within a principal-agent approach.
} 
(Grant and Keohane 2005, 30). First, accountability requires information on policies, such as repression, being available to citizens and the international community. Second, if there is evidence of wrongdoing, some punishment is expected to follow. These conditions, joint information and conditional punishment, help identify which countries are most likely to be held to account for violence, as well as which states might be best situated to use informal militias to reduce their liability.

Accountability, both domestic and international, is central to understanding governments' use of repression (Bueno de Mesquita et al. 2005). We argue that governments seek to lower accountability for violence using the militia's organizational separation from regular security forces. This separation increases the problems of delegation. It worsens the information asymmetries concerning the implementation of repression, enabling the government (as principal) to claim it cannot control the militias (as agent). The separation makes it more difficult for accountability holders to trace the responsibility for violence back to the government. This process is similar to what Fiorina (1985) described as delegation to "disguise." Without being able to clearly establish responsibility for the violence, holding leaders to account, either by citizens or by the international community, is more difficult. This political incentive to use informal militias depends on the presence of domestic or international accountability mechanisms.

If our understanding of the incentives for government repression and the perceived usefulness of militias in avoiding accountability is correct, then we should see informal links between governments and militias not just in isolated cases where governments have yet to achieve sovereignty, but in many places around the world where governments fear negative sanctions for the use of violence. 
One might question the likely success of this form of avoiding accountability, particularly when open source and media accounts reveal these ties. Yet governments often operate with a minimal view of what is required for denials. "The point is not to persuade audiences to agree with the account — that is, to support the action—-but to make it sound credible and reasonable" (Cohen 2001, 62). With regular forces on the border and available to invade or to interdict proRussian militias, such as the Vostok Battalion operating in the Ukraine, and despite evidence in the worldwide media of their supply of these forces, the Russian government persisted in denying control over the Vostok Battalion: " He [Putin] was trying to maintain an element of deniability, which he would be unable to do if he had sent regular Russian troops" (Judah 2014, 77). Grant and Keohane make this point: "in world politics, accountability for most powerwielders is likely to be less constraining than is optimal" $(2005,40)$. Even flimsy denials of responsibility for the activities of "rogue elements" in these groups may prove sufficient to create some reasonable doubt about the government's accountability.

\section{Information, Government Sensitivity, and Reduced Liability}

Leaders' sensitivity to accountability for using militias varies with the government's ability to suppress information on links to militias, and with the conditional costs incurred if their responsibility were revealed. Governments may face domestic and international accountability mechanisms.

Domestically, democratic leaders may expect to be punished for using violence since democratic institutions enable voters to sanction the government's behavior with loss of public support or office. For example, Prime Minister Recep Tayyip Erdogan's approval rating dropped 
10 points within months of cracking down on protesters in Istanbul in late May 2013 (Peter 2013). Leaders in democracies may align with informal armed groups if they expect to shift responsibility for their actions. Informal linkages to militias might be quite easy for all governments to keep secret, since even full democracies have the power to keep official secrets (Colaresi 2014). However, in a full democracy with free speech and open information, secrecy is more difficult to maintain compared to incomplete democracies. This argument is in line with the finding that "full democracy" (Davenport and Armstrong 2004), reduces violations of human rights due to mechanisms of domestic accountability (Cingranelli and Filippov 2010). Bueno de Mesquita, Downs, Smith and Cherif argue "limited accountability generally retards improvements in human rights" $(2005,439)$. Governments in weak democracies are more likely to expect to be able reduce pressure to adhere to human rights standards by using militias to limit accountability:

H1: Informal government-militia ties are more likely in weak democracies compared to full democracies or non-democracies.

Leaders in strong autocracies have less fear of the domestic costs of official repression. Information asymmetries in autocracies are more severe than in other regime types. They are unlikely to have interest groups and "fire alarm" monitoring (Banks and Weingast 1992). Repression, even by the state security apparatus, may go unreported. If reported, it is usually very costly for citizens to sanction leaders. Where accountability mechanisms are absent, there is less incentive to use informal pro-government militias:

$\mathrm{H}$ 2: Informal government-militia ties are less likely in autocracies than in other regime types. 
Research by Landman (2005) and others (e.g. Simmons 2009; Levitsky and Way 2010) extends the domestic logic of accountability to the international community. Leaders fear financial or even legal sanctions from external actors, whether other governments, international organizations, or courts. Democratic donor states and international organizations may punish leaders breaking human rights commitments (Landman 2005, Risse, Ropp, Sikkink 1999, Simmons 2009, Kirschke 2000, Roessler 2005, Levitsky and Way 2010). Leaders may fear the threat of legal action through international tribunals and financial sanctions from democratic donors (Simmons 2009, Kirschke 2000, Roessler 2005). Since the 1970s, the United States is required by law to consider the human rights performance of recipient states in aid decisions and the European Union's commitment to human rights is considered fundamental to its external relations. ${ }^{5}$ For example, European Foreign Ministers threatened to delay talks about Turkey joining the EU after the May 2013 crack-down on protesters. ${ }^{6}$

While Grant and Keohane (2005) caution that international monitoring is more difficult than domestic monitoring, developed democracies have used their financial leverage in an effort to protect human rights (Kirschke 2000, Roessler 2005, Levitsky and Way 2010). Research is mixed on the consistency with which aid sanctions are applied (Nielsen 2013), yet it is unnecessary to assume democratic aid donors are consistent or sincere in their commitments to human rights. If leaders aid human rights violating regimes, or even visit them (e.g., Prime Minister Cameron's visit to Sri Lanka in 2013), they risk political or reputational costs. Aid sanctions and even selective application leave repressive regimes uncertain about the prospect of accountability, providing an incentive to seek to avoid accountability for repression.

\footnotetext{
5 The EU's "foreign policy instruments ... and financial assistance help strengthen democracy and human rights in the world. Respect for human rights is also one of the preconditions for any candidate country's accession to the EU." http://europa.eu/legislation summaries/human rights/human rights in third countries/index en.htm 6 "EU delays Turkey membership talks after German pressure" BBC World, June 25, 2013, available at http://www.bbc.co.uk/news/world-europe-23044600.
} 
Leaders in partial democracies and dependent on support from democracies have an incentive to outsource the use of violence to avoid reputational and tangible consequences for using repression. ${ }^{7}$ Consistent with case research (Kirschke 2000; Roessler 2005), we argue that governments dependent on aid from democracies are more likely to make use of militias to reduce liability for repression. An autocracy not reliant on support from democracies or fearful of other forms of intervention by the international community, such as the Soviet Union during the Cold War or North Korea today, has less fear of the costs of official repression.

H3: Informal government-militia ties are more likely in states that receive aid from democracies, compared to states that do not receive aid from democracies or that receive aid from autocracies.

Aid from democratic countries makes leaders vulnerable to conditional sanctions, providing the motivation to seek ties to informal armed groups. But only countries that expect to get away with this strategy will take this risk. In countries that are difficult for the international community to monitor, informal ties might escape notice. Since accountability relies on the joint combination of potential sanctions and information, we explore the possibility that the use of unofficial militias increases for recipients of democratic aid as the monitoring costs of the donors and the remoteness from donor democracies increases:

\footnotetext{
${ }^{7}$ Nielsen (2013) points to the political costs for donors seen to support repressive regimes. For donor countries with strategic priorities, but with human rights constraints on aid policies, pointing to the recipient government's incomplete control of those committing violence may provide some 'credible if not persuasive' defense of their support for repressive allies. Also, if democratic states refuse aid to countries that they expect in the future will utilize militias to repress their populations and avoid monitoring, then higher democratic aid should lower the probability of informal PGMs. The analysis controls for GDP and military strength, which might influence the likelihood of aid and of militia presence.
} 
H4: Informal government-militia ties are more likely in states that receive aid from democracies but are difficult for donor democracies to monitor, compared to other types of states.

Before testing these hypotheses on a global sample, some examples help illustrate the argument.

\section{CASE EXAMPLES OF INFORMAL TIES TO MILITIAS AND AVOIDING} ACCOUNTABILITY

The examples of Sudan and Bosnia illustrate the use of militias to avoid international sanctions for violence. The International Criminal Court (ICC) sought the arrest of the president of Sudan for the atrocities in Darfur carried out by armed militias. According to the ICC prosecutor, the president, although denying control over the militias, was criminally responsible for their acts: "They all report to him, they all obey him. His control is absolute" (ICC Press Release 2008). In December 2014 the ICC prosecutor suspended the investigation, ${ }^{8}$ but if the president is ever arrested, he may take encouragement from the acquittal of Serbian officials for war crimes committed by Arkan's Tigers.

Serbian officials denied responsibility for this militia, but The Washington Post noted that "Milošević's control is tight enough over Arkan's units that they would not be operating on a free-lance basis" (Pomfret 1994; The Economist 14 October 1995). Despite the flimsy basis for denial, Serbian Security Service officials avoided accountability. The International Tribunal for the Former Yugoslavia found that Serbian officials had aided the groups. But "it was not proven

\footnotetext{
8 “Sudan President Hails 'Victory' over ICC Charges" http://www.bbc.co.uk/news/world-africa-30467167.
} 
beyond reasonable doubt that Stanišić or Simatović planned or ordered the crimes." ${ }^{\text {" With a }}$ "credible if not persuasive" defense they were acquitted on all charges.

In addition to legal liability for repression, militias may limit financial liability for aid dependent countries. In Cameroon, Rwanda, and Kenya, pressure from international aid donors to democratize, combined with pressure from internal opposition groups, led states to use informal repression "to avoid criticism by donors for human rights violations, but also to regain control over the transition process by covertly suppressing political conflicts" (Kirschke 2000, 385). In 1991, the United States and other donor countries pressured President Moi into legalizing opposition parties and elections were held in 1992. But as in Rwanda and Cameroon, the government shifted to "informal repression, violations by surrogate bodies such as hit squads, party youth wings and traditional leaders, against perceived and real government critics" (Kirschke 2000, 397). Donor-induced democratization saw violence "carried out by nonstate actors, such as vigilantes, paramilitaries, and militias, who are directly or indirectly supported by the government" (Roessler 2005, 209).

Governments collaborate with militias to shift blame and redirect the flow of information about responsibility for violations from regular to irregular forces. This is a joint or "collusive" relationship (Staniland forthcoming), not a "substitute" relationship where regular forces then "refrain" from violations (Cohen and Nordas forthcoming; Stanton forthcoming). The logic of delegation predicts increased violations and more agent-centered violations (e.g., sexual violence) where militias are present, and commensurate opportunities shift blame to these

\footnotetext{
${ }^{9}$ UN ICTY http://www.icty.org/sid/11329
} 
groups, but not that regular forces desist from violations (Mitchell 2004). ${ }^{10}$ The logic also predicts high levels of agent-centered violations with similarly ill-disciplined or ill-motivated regular forces (e.g., Bohara et al. 2008). Examining sexual violence Brysk (2014, 6) says "the Congolese state ... assert the problem is centered in militias rather than national forces," but she highlights the responsibility of national forces as well as militias for these crimes. The Syrian government recruited the Shabiha militia from its prisons in 2011 to take the blame for atrocities (Sunday Telegraph March 23, 2014). But both regular forces and militias continued to commit violations according to the United Nations (2013). Publicity about government violations may bring tangible costs for countries in receipt of aid (Nielsen 2013), or it may make it easier to support the government's opponents - a plausible concern of the Assad government and an incentive to outsource.

These examples highlight the use of militias to reduce accountability. Across the cases, governments complicit in militia violence were at least partially successful in reducing the costs of being associated with excessive violence. The cases illustrate the complexity of accountability processes and the moral hazard of international aid or legal interventions, which might inadvertently create an incentive to use militias.

Before we empirically test our argument, we analyze the claim that militias offer logistical benefits to governments facing civil violence and disorder. Under such conditions, governments might use irregular armed groups as a quick and cost-effective way of deploying forces or gaining information advantages (Alvarez 2006; Jentzsch, Kalyvas, and Schubiger forthcoming). In this "Disorder Model," we analyze the impact of civil war and dissent on the

\footnotetext{
${ }^{10}$ While lowering the costs of violence for governments, these groups also have their own agendas, and recruitment procedures are likely rudimentary. They attract violence-prone individuals (Alvarez 2006) to an organization that lacks discipline, training, and compensation to properly manage the delegation of violence. The motives of individual militia members may vary, and normative commitments are likely to impact the use of violence (Paper 7).
} 
existence of informal government-militias links, controlling for level of development and population size. This model provides a benchmark to gauge the explanatory power of our accountability-avoidance mechanisms.

\section{Measuring Informal Government-Militia Ties}

We test our arguments using the Pro-Government Militias dataset (PGMD), containing information on whether an unofficial government-militia security tie existed in a given countryyear (Carey, Mitchell, and Lowe 2013). We focus on informal groups, which do not have an officially recognized or legal relationship with the government. ${ }^{11}$ The presence of informal government-militia ties is captured with a dummy variable with any informal governmentmilitia tie coded one and zero otherwise. Where there is no clear end date for this relationship, we use the last date of militia activity as proxy.

Global data require concepts that travel cross-nationally and over time. Names of groups are culture-bound, vary regionally and over time, and are not a reliable indicator of a group's properties. Campbell and Brenner (2000) include within the same analytical framework groups labeled death squads in Central America, vigilantes in the Philippines, paramilitaries in Serbia and Weimar Germany, militias and secret armies in India. An issue for future research raised by Jentzsch, Kalyvas, and Schubiger (forthcoming) is how to classify sub-types of militias that hinge on theoretically important distinctions. ${ }^{12}$

\section{MEASURING THE INCENTIVES TO AVOID ACCOUNTABILITY}

\footnotetext{
${ }^{11}$ For definitions and coding procedures, see Carey, Mitchell, and Lowe (2013). Since governments seek to hide links to militias, one concern is missing information. However, the sources used for historical coding back to 1981 are greater than those available at the time. We use data until 2005 in this analysis.

${ }^{12}$ To illustrate we also ran analyses that dropped groups labeled "death squads" (English) from the analysis, shown in the appendix.
} 
We measure the incentive and ability to avoid domestic accountability with political institutions. Strong Autocracies are coded as countries that score -7 or lower on the Polity2 scale (Marshall, Jaggers and Gurr, 2010). Weak Democracies are coded as countries that score between 1 and 6 on that scale. Strong Democracies are coded as countries with the score 7 or above on the Polity2 scale. The omitted category is weak autocracies. We also include the underlying Polity2 index, which ranges from -10 to 10 as a non-linear term in a generalized additive model to check whether a more flexible functional form provides evidence consistent with our hypotheses. ${ }^{13}$

We measure international sensitivity with aid dependence, utilizing the AID 2.0 database to measure aid transactions. We code the purchasing-price parity adjusted value of aid sent from democracies (at least 7 on the Polity2 scale), to any recipient. We compute Democratic aid dependency as the natural log of the sum total of aid received from democracies as a proportion of the recipient's GDP. ${ }^{14}$ To capture monitoring costs for the international community, we measure the distance (in kilometers) between each country and the nearest democracy. We follow Tobler's law, which suggests "near things are more related than distant things," and assume that informal government-militia partnerships that are distant from democracies will be more difficult to detect due to greater inattention or fewer resources. As human rights monitors specify, distance inhibits monitoring due to less dense informational ties that can reliably collect information. ${ }^{15}$ Distance to democracy is coded zero if the state is a democracy or a neighbor is a democracy, using the C-Shapes data (Weidmann and Gleditsch 2010), and then logged. ${ }^{16} \mathrm{We}$ also explore whether proximity to a democracy and democratic aid interact to jointly make

\footnotetext{
${ }^{13}$ As the GAM results make clear, small changes to the thresholds for the categories do not alter our inferences.

${ }^{14}$ When log-transforming the vector of aid scores we add one-half of the smallest, non-zero value, since they included zeros.

${ }^{15}$ See the Norwegian Resource Bank for Democracy and Human Rights (NORDEM), as well as the Norwegian Centre for Human Rights at the University of Oslo, "Manual on Human Right Monitoring," Norwegian Resource Bank for Democracy and Human Rights, Chapter 6, pg. 7, available at http://www.jus.uio.no/smr/english/about/programmes/nordem/publications/manual/current/kap6.pdf.

${ }^{16}$ When log-transforming the distance to democracy scores we added one-half of the smallest, non-zero value.
} 
informal government-militia ties more likely, given that if a regime does not depend on foreign aid from democracies, then the international community has less leverage, regardless of the distance to the nearest democracy. As distance may be an imperfect measure of monitoring costs, we use absence of media access (Norris 2008) as an alternative. ${ }^{17}$ This indicator is only available for a subset of our observations, but provides a useful validation of our inferences using distance to the nearest democracy. The results are presented in the appendix.

\section{THE EMPIRICAL LEVERAGE OF AUTOCRATIC AID}

Autocratic states are unlikely to be concerned about repression abroad. Therefore, aid from this source is unlikely to encourage recipient countries to outsource violence to militias. If democratic aid makes informal government-militia ties more likely, as expected, but autocratic aid does as well, then this would suggest that it is aid and not international monitoring by democracies that explains the use of PGMs. If, however, aid from democracies increases the presence of informal government-militia linkages, but not aid from autocracies, then this supports our conditional punishment argument. We therefore include Autocratic aid dependency in our specification. ${ }^{18}$

\section{ANALYZING THE DISORDER MODEL}

We first analyze the impact of domestic disorder on the probability of government-militia linkages. Then we compare whether our accountability model improves our understanding of the

\footnotetext{
${ }^{17}$ We reverse the media scale to match the argument concerning monitoring costs. It should be more difficult to monitor a country with less media. The media scale equals the sum of per capita televisions, newspapers, radios, and internet users divided by four (Norris 2009, 3). The correlation between the distance to the nearest democracy and the absence of media scale is .49. The results are in the appendix and are consistent with the inferences using the distance measure.

${ }^{18} \mathrm{We}$ control for the time since the last PGM presence using cubic splines in several specifications to measure potential non-linear deterministic trends in the probability of informal militia links.
} 
use of militias. We measure disorder with current domestic unrest using the Cross-national Times Series (CNTS) data (Banks 2008) and code Strikes, Riots, Demonstrations, and Guerrilla attacks into a set of dichotomous variables. We measure civil violence and war with the UCDP/PRIO Armed Conflict Data (ACD) (Gleditsch et al., 2002), using Civil violence to measure armed conflict above the threshold of 25 battle-related deaths within one year and Civil war capturing civil wars that have crossed the 1,000 battle-related deaths threshold. Including both Civil violence and Civil war allows us to capture the effects of varying levels of violence within the disorder framework. Excluding one of these variables treats all non-civil war years as equal and assumes that civil violence and civil war have the same effect on government-militia linkages. ${ }^{19}$ We control for Economic development with the log of real GDP per capita from the Penn World Tables and for Population, which is logged and coded using the Correlates of War data, version 4.0 (Singer 1987). We also measure Ethnic fractionalization (Fearon and Laitin 2003) to evaluate whether an ethnically more heterogeneous society increases the likelihood of government-militia collaboration.

When comparing our hypotheses with the Disorder Model we rely on generalized additive models to allow for flexible functional forms where appropriate, as well as a flexible interaction between aid from democracies and the distance to the nearest democracy. However, increasingly complicated specifications with greater flexibility are more likely to overfit the idiosyncrasies of the data. Therefore, we compare fits using AIC, which penalizes models with more parameters. To have a lower (thus better) AIC score, the added explanatory payoff must be greater than the added complexity. Additionally, we investigate out-of-sample fits between the

\footnotetext{
${ }^{19}$ We explored whether constraining the coefficients for strikes, riots, and demonstrations and also civil violence and guerilla activity to be equal improved the model. It reduced the in-sample fit based on AIC and the forecasting performance. Therefore, we use the indicators separately. We conducted joint tests of significance to analyze whether we can reject the null hypothesis that the coefficients for some or even all of the disorder coefficients are zero, or whether we can reject the hypothesis that they are all jointly zero.
} 
Disorder Model and the Accountability Avoidance Model. A specification that is fitting idiosyncrasies in the sample data, rather than systematic patterns, will fit well in-sample but not out-of-sample. We use separation plots (Greenhill, Ward, and Sacks 2011) to present the out-ofsample results and report Brier scores. ${ }^{20}$

\section{Results}

The first column in Table 1 presents the results of the baseline Disorder Model. Strikes, riots, demonstrations, guerrilla attacks, civil violence, and civil war increase the probability of an informal government-militia relationship within a country. However, it is only demonstrations, guerrilla attacks, and civil violence that have substantially larger point estimates compared to their associated standard errors.

While strikes, riots, and civil wars have smaller coefficients relative to their uncertainty estimates, this appears to be due to the covariance between these measures, as there is a similar bivariate relationship between these variables and informal government-militia ties compared to the bivariate relationship between riots and these unofficial ties. In addition, civil violence is present in all cases of civil war, so that the civil war parameter is measuring the difference between civil violence and war. These six variables are jointly statistically significant using a Wald test. ${ }^{21}$ We can reject the null hypothesis that the effect of strikes, demonstrations, and riots on PGM presences is jointly zero at the .01 level. ${ }^{22}$ Decreasing GDP also increases the probability of an informal government-militia tie, as does increasing the population size, likely

\footnotetext{
${ }^{20} \mathrm{We}$ also explored whether having a smaller military might make informal PGMs more likely. Including the number of military personnel per capita did not alter our inferences; the results are presented in the appendix. We thank an anonymous reviewer for the suggestion.

${ }^{21}$ The test-statistic is 86.82, with six degrees of freedom and $\mathrm{p}<0.001$.

${ }^{22}$ The test-statistic is 21.41 with three degrees of freedom and $\mathrm{p}<0.001$.
} 
reflecting deployment efficiencies gained from militia ties. Our estimate for ethnic fractionalization is negative, with a standard error over three times the size of the point estimate.

TABLE 1 A Logit Analysis of Informal Government-Militia Linkages

\begin{tabular}{|c|c|c|c|c|c|}
\hline \multirow[b]{2}{*}{ Disorder } & \multicolumn{2}{|c|}{$\begin{array}{c}\text { Model } 1 \\
\text { Disorder Model }\end{array}$} & $\begin{array}{c}\text { Model } 2 \\
\text { Accountability } \\
\text { Avoidance }\end{array}$ & \multicolumn{2}{|c|}{$\begin{array}{c}\text { Model } 3 \\
\text { Combined Model }\end{array}$} \\
\hline & & & & & \\
\hline Strikes & 0.38 & $(0.28)$ & & 0.28 & $(0.29)$ \\
\hline Riots & 0.23 & $(0.24)$ & & 0.27 & $(0.25)$ \\
\hline Demonstrations & $0.62 * *$ & $(0.22)$ & & $0.55^{*}$ & $(0.23)$ \\
\hline Guerrilla attacks & $0.50 *$ & $(0.24)$ & & 0.29 & $(0.25)$ \\
\hline Civil violence & $1.12^{* * *}$ & $(0.22)$ & & $1.14^{*}$ & $*(0.22)$ \\
\hline Civil war & 0.36 & $(0.32)$ & & 0.38 & $(0.34)$ \\
\hline \multicolumn{6}{|l|}{ Control variables } \\
\hline Economic development & $-0.65 * * *$ & $(0.10)$ & & $-0.27 *$ & $(0.14)$ \\
\hline Population & $0.33 * * *$ & $(0.07)$ & & $0.33^{*}$ & $*(0.07)$ \\
\hline Ethnic fractionalization & -0.10 & $(0.32)$ & & -0.09 & $(0.34)$ \\
\hline \multicolumn{6}{|l|}{ Domestic accountability } \\
\hline Weak democracies & & & $0.52 * *(0.20)$ & $0.55^{*}$ & $(0.22)$ \\
\hline Strong autocracies & & & $(0.28)$ & 0.03 & $(0.29)$ \\
\hline Strong democracies & & & $(0.32)$ & 0.12 & $(0.38)$ \\
\hline \multicolumn{6}{|l|}{ International accountability } \\
\hline Distance to democracy & & & $0.19 * \quad(0.10)$ & 0.15 & $(0.11)$ \\
\hline Aid from democracies & & & $0.24 * * *(0.03)$ & $0.16^{*}$ & $*(0.04)$ \\
\hline Aid from autocracies & & & $-0.09 * * *(0.02)$ & $-0.10^{*}$ & $*(0.03)$ \\
\hline Intercept & $-1.86^{*}$ & $(0.95)$ & $-5.70 * * *(0.65)$ & $-6.90^{*}$ & $*(1.52)$ \\
\hline $\bar{N}$ & 3270 & & 3270 & 3270 & \\
\hline AIC & 1038.2 & & 1123.1 & 1002.6 & \\
\hline
\end{tabular}

Standard errors in parentheses. ${ }^{*} \mathrm{p}<.1,{ }^{* *} \mathrm{p}<.01,{ }^{* * *} \mathrm{p}<.001$ (two-tailed test)

Substantively, the Disorder Model estimates how increasing the risk of disorder is likely to impact the probability of informal government-militia ties, irrespective of the incentive to avoid accountability. Moving from a low risk scenario where a country has a population and GDP per capita at the sample median and no riots, demonstrations, or other forms of civil violence, to a higher risk country with a population at the third quartile without increasing GDP 
per capita proportionally ${ }^{23}$, and is suffering from civil violence, increases the probability of an informal government-militia from 2 percent $(90 \%$ CI: .01 to .04$)$ to 14 percent ( $90 \%$ CI: .08 to .22). These results support the argument that government-militia ties are more likely in situations of domestic disorder. As we show below, accounting for the risk of being held accountable for violence substantially improves the predictive power of our models.

TABLE 2 Generalized Additive Analysis of Informal Government-Militia Linkages

\begin{tabular}{|c|c|c|c|c|}
\hline \multirow[b]{2}{*}{ Disorder } & $\begin{array}{c}\text { Model } 4 \\
\text { 1-D Smooth with } \\
\text { Baseline }\end{array}$ & \multirow[t]{2}{*}{$\begin{array}{c}\text { Model } 5 \\
\text { 2-D Smooth without } \\
\text { Baseline }\end{array}$} & \multicolumn{2}{|c|}{$\begin{array}{c}\text { Model } 6 \\
\text { 2-D Smooth with } \\
\text { Baseline }\end{array}$} \\
\hline & & & & \\
\hline Strikes & $(0.29)$ & & 0.26 & $(0.29)$ \\
\hline Riots & $(0.25)$ & & 0.27 & $(0.25)$ \\
\hline Demonstrations & $(0.23)$ & & $0.48 *$ & $(0.23)$ \\
\hline Guerrilla attacks & $(0.25)$ & & 0.32 & $(0.26)$ \\
\hline Civil violence & $(0.23)$ & & $1.17 * * *$ & $(0.23)$ \\
\hline Civil war & $(0.33)$ & & 0.39 & $(0.33)$ \\
\hline \multicolumn{5}{|l|}{ Control variables } \\
\hline Economic development & $-0.30 * \quad(0.14)$ & & $-0.44 * *$ & $(0.17)$ \\
\hline Population & $0.34 * * *(0.08)$ & & $0.38 * * *$ & $(0.09)$ \\
\hline Ethnic fractionalization & $(0.34)$ & & -0.16 & $(0.35)$ \\
\hline \multicolumn{5}{|l|}{ International accountability } \\
\hline Aid from autocracies & $-0.10 * * *(0.03)$ & $-0.10 * * *(0.02)$ & $-0.09 * * *$ & $(0.03)$ \\
\hline Intercept & $-5.82 * * *(1.30)$ & $-4.49 * * *(0.25)$ & $-4.93 * * *$ & $(1.36)$ \\
\hline Smooth Estimates & (Chi-sq) & (Chi-sq) & EDF & (Chi-sq) \\
\hline Aid from democracies & $1.00 * * \quad(9.48)$ & & & \\
\hline Distance to nearest democracy & $(9.78)$ & & & \\
\hline Polity & $4.27 * * \quad(16.63)$ & $4.08 * * *(21.25)$ & $4.29 * *$ & $(16.46)$ \\
\hline Aid from Demo. \& Dist. (2-D) & & $13.65 * * *(84.78)$ & $11.02 *$ & $(28.46)$ \\
\hline $\mathrm{N}$ & 3270 & 3270 & 32 & 70 \\
\hline $\mathrm{AIC}$ & 987.8 & 1093.7 & $98^{\prime}$ & 7.2 \\
\hline
\end{tabular}

Standard errors in parentheses. Smooth estimates are non-linear relationships examined with a Chi-square test. EDF refers to the estimated degrees of freedom for the smooth term. ${ }^{*} \mathrm{p}<.1,{ }^{*} \mathrm{p}<.01, * * * \mathrm{p}<.001$ (two-tailed test)

${ }^{23}$ As GDP remains constant, while the population increases, GDP per capita drops proportionally. 


\section{AVOIDING ACCOUNTABILITY}

To explore our argument that militias are more attractive in circumstance where leaders have incentives and opportunities to avoid accountability, the second and third set of columns in Table 1 show the results from our Accountability Avoidance Model, with measures of regime type, the amount of aid from democracies, the distance to the nearest democracy, and aid from autocracies, alone (second column in Table 1) and in combination with the disorder measures (third column in Table 1), since we view these incentives as complementary.

\section{DOMESTIC ACCOUNTABILITY}

In each specification, we find support for the argument that governments use militias when they jointly have the incentive and ability to avoid accountability for violence. The results show that the probability of informal militia ties varies with regime type (see Table 1, columns 2 and 3, and Figure 1). A test that all of the regime categories have the same probability of informal militias is rejected at the .05 level for both models. Further, with both specifications weak democracies have the highest probability of informal militia presence and autocracy (including the excluded weak autocracy category) lowers the probability of having an informal militia. ${ }^{24}$ These results provide evidence that weak democracies have a significantly higher probability of having informal militias, and that it is more difficult to differentiate the categories of strong autocracies, weak autocracies, and strong democracies.

\footnotetext{
${ }^{24}$ Because this set of variables is categorical, we cannot interpret the raw coefficients as representing differences across all comparisons, but only against the baseline excluded category of weak autocracies. The positive coefficient for weak democracies represents the expectation that governments in weak democracies are more likely to have informal relationships with militias than weak autocracies. We can also test the equality of the estimated coefficients to see whether other differences are meaningful. Table 1, Model 2 shows that strong autocracies have a significantly lower probability of informal militias compared to weak democracies (Chi-square $=9.9, \mathrm{df}=1, \mathrm{p}<.001$ ) and strong democracies (Chi-square $=5.2, \mathrm{df}=1, \mathrm{p}<0.025$ ), but that the difference between weak democracies and strong democracies (Chi-square $=0.02, \mathrm{df}=1, \mathrm{p}=0.87$ ) may be due to chance in this specification. The GAM model presented below provides clearer evidence on this last point.
} 
The analyses in Table 1 assume that the probability of informal government-militia relationships jumps across categories instead of smoothly varying with the underlying democracy index, and that we have a priori specified the jump locations correctly. This can be seen in the first panel of Figure 1, which plots the estimated probability of an informal militia and the 90 percent confidence interval from Model 2 in Table 1 for the 4 categories (strong autocracy, weak autocracy, weak democracy, and strong democracies) by the Polity2 scale that was used to create the categories. Each category is assumed to have a constant probability of a militia, while changes can only occur across categories.
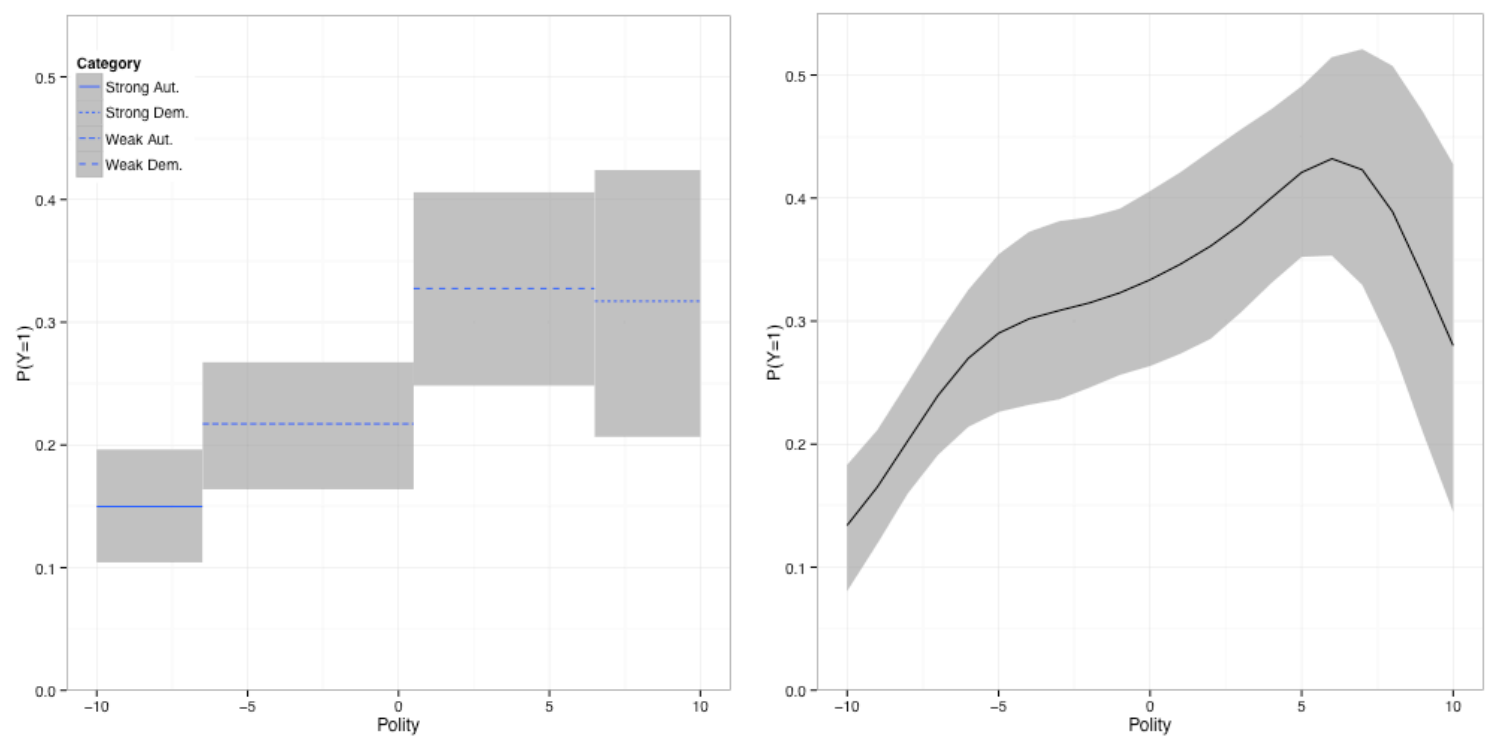

FIGURE 1. Probability of Unofficial Government-Militia Ties in Different Regime Types

Table 2 estimates three generalized additive models that allow for flexible splines to fit the data to relax the assumption of linearity on the log odds scale for democracy and other variables of interest. We include the underlying Polity2 index as a continuous covariate without assuming a specific functional form for the relationship between regime types and the probability 
of informal government-militia ties. ${ }^{25}$ Because these models no longer have only one parameter describing the change in the dependent variable, Table 2 presents the joint significance tests and estimated degrees of freedom for these non-linear relationships (smooth terms) and the AIC for each model, along with any linear terms that were included. The nonlinear relationships are best presented graphically.

The second graph in Figure 1 plots the estimated relationship and standard error from the GAM in the second model in Table 2. The probability of an informal government-militia relationship rises steadily as autocracy decreases, peaking rather sharply between the weak democracy and strong democracy categories (near six and seven on the Polity2 scale), before dropping again as a state reaches full democracy. The AIC statistics across Table 2 suggest that the GAM specification is a better fit to the data even after penalizing the model for adding additional parameters. Only replacing the categorical regime variables in Model 3, Table 1 with the spline results in a reduction (improvement) of the AIC from 1002.6 to 995.1.

In this model, weak democracies have three times the relative risk of informal government-militia ties compared to strong autocracies and 1.4 times the relative risk compared to strong democracies, consistent with hypotheses $\mathrm{H} 1$ and $\mathrm{H} 2$. As expected, states that are most likely to be held accountable for official repression, but might get away with using informal militias due to incomplete freedoms of speech and the press, are the most likely to have these ties. This nonlinear relationship is consistent across all three models in Table 3.

\footnotetext{
${ }^{25}$ The models are fit using the package mgcv in R. The smooths are thin plate regression splines for the polity 2 score.
} 


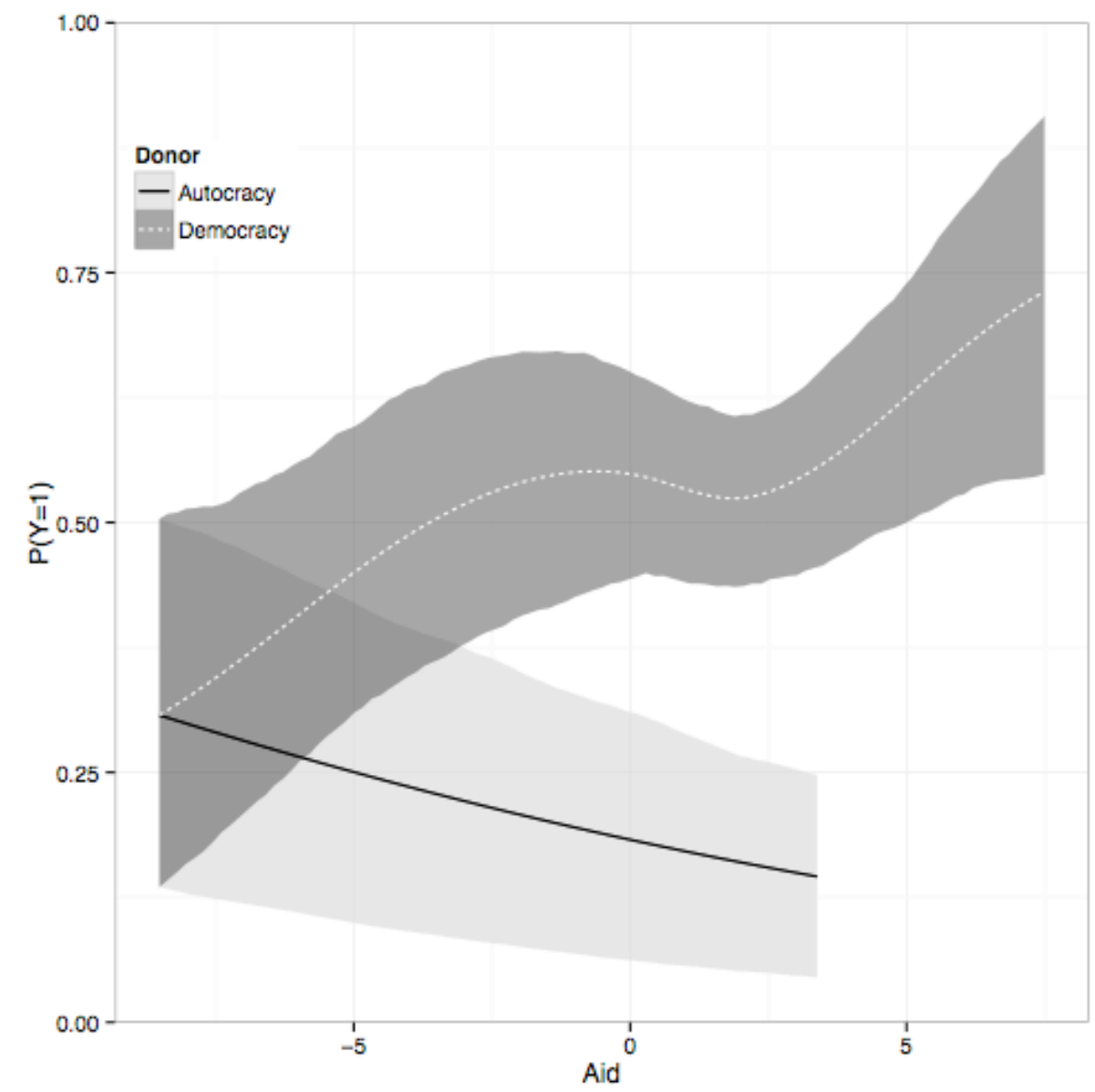

FIGURE 2. Predicted Probability of Unofficial Government-militia Linkages Depending on Aid Dependency by Donor's Regime Type

Note: Democratic aid is represented with a dotted white, autocratic aid with a solid black, with 90 percent confidence intervals. These results are for a country that is at the 75th percentile of distance.

\section{INTERNATIONAL ACCOUNTABILITY}

Our results support the argument that international accountability motivates the use of militias. Aid from democracies should increase the likelihood of ties to militias and the distance from the nearest democracy should increase the perceived ability to hide ties to militias. Aid from autocracies should decrease the likelihood of these ties since autocracies are unlikely to hold aid 
recipients responsible for repression. Comparing the results from the $\operatorname{linear}^{26}$ specifications in Table 1 to the GAM results in Table 2 suggests that aid from democracies increases and aid from autocracies decreases the probability of government-militia ties. ${ }^{27}$ Thus, across different specifications $\mathrm{H} 3$ is supported. Figure 2 presents the differing slopes depending on whether the donor was a democracy or an autocracy, using the coefficients from Model 3, Table $2 .^{28}$ The dotted white line with the accompanying darker confidence interval maps the non-linear but largely increasing relationship between democratic aid and informal militia ties for a state that is very distant from a democracy. The black line with lighter shaded confidence intervals maps the negative relationship between autocratic aid and the predicted probability of informal militia linkages.

Across the models, distance to the nearest democracy is estimated to increase the probability of informal ties, but the variability around this estimate suggests greater uncertainty about its additive effect. However, the best fitting model (Model 3, Table 2), by AIC, includes the non-linear interaction for aid from democracies and distance to the nearest democracy (Hypothesis 4), measuring cases that have both the incentive (keeping aid from democracies) and the opportunity (less precise monitoring due to distance from a democracy) to use a militia without suffering international accountability costs. The shape and significance of this interaction supports Hypothesis 4 . Model 3 in Table 2 includes a two-dimensional tensor product smooth of distance and aid from democracies. The model can be thought of as suspending a flexible sheet, rather than a flat plane, through the data.

\footnotetext{
${ }^{26}$ These specifications are linear in the log odds.

${ }^{27} \mathrm{We}$ attempted to fit smooth terms to the autocratic aid measure, but the linear model provided a superior fit based on AIC, and the smooth terms returned a linear functional form.

${ }^{28}$ This was calculated with the continuous covariates set at their mean and categorical variables set at their modes, with distance to the nearest democracy at the $90^{\text {th }}$ percentile. The lines are only plotted over the range of the available sample data. The overlap of the confidence intervals is overstated because it does not take into account the covariance between the two parameters. Regardless, the different patterns are clear and the parameter differences bear this out (see Model 2 and Model 3 in Table 1 for a linear comparison).
} 
The estimated relationship between democratic aid conditional on distance and the probability of an informal government-militia relationship is shown in Figure 3 in a wireframe and a contour plot. Both present the predicted probability for unofficial government-militia ties for a weak democracy with civil violence, median GDP, and population, based on Model 3 in Table 2. States that receive large amounts of aid from democracies and are far away from the nearest democracy are most likely to have informal government-militia ties. The estimated probability of such a tie increases from $.2(90 \% \mathrm{CI}$. .1 to .3$)$ for a state that receives no aid from a democracy and shares a border with a democracy to over $.8(90 \% \mathrm{CI}$ : .5 to .9$)$ for a state that is over 1500 kilometers from the nearest democracy and receives aid from democracies at the 75 th percentile. $^{29}$

This plot also shows that the relationship between democratic aid and informal government-militia collaboration depends on the monitoring costs. Along the bottom edge of the contour plot the probability of informal militia-government rises only gently from .2 to .4 as aid increases. At the upper edge of the plot, for states that are distant from democracies, the probability increases from .3 to over .8 .

The lower AIC value for the combined models (3rd set of columns in Tables 1 and 2), compared either to the Disorder or the Accountability Avoidance Model, suggests that the disorder and accountability mechanisms are complementary; they are both useful for predicting informal militia relationships. The lower AIC value for the combined model that includes nonlinear terms (Model 3 in Table 2) compared to the linear model (Model 3 in Table 1) shows that the flexibility of the generalized additive model framework is helpful in predicting informal militia ties.

\footnotetext{
${ }^{29}$ These predicted probabilities are for a weak autocracy suffering current disorder, all other variables set at either their medians for continuous variables or modes for discretely valued measures.
} 
Combining accountability avoidance with disorder measures substantively increases the probability of unofficial government-militia relationships. An autocracy with civil violence, but aid from other autocracies and not democracies, has only an expected one percent probability (90\% CI: .01, .03) of having an informal militia relationship. However, a weak democracy, with the same degree of civil violence, getting aid from a distant democracy, has over an 80 percent risk $(90 \% \mathrm{CI}: .5, .9)$ of having such a relationship.
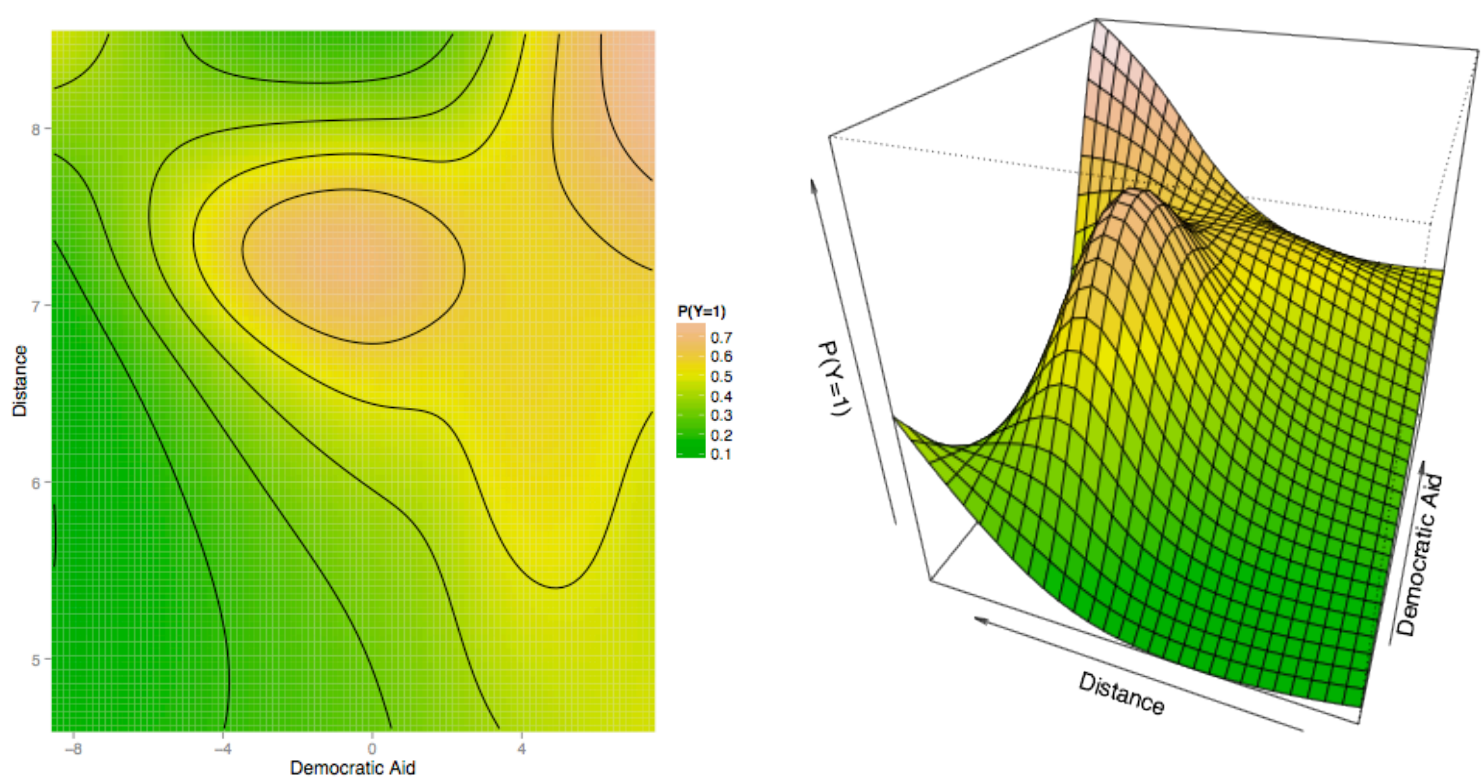

FIGURE 3. Incentives and Opportunities for Unofficial Government-Militia Ties

Note: Distance to democracy is measured in log $\mathrm{km}$, and democratic aid as logged proportion of GDP, and response as the predicted probability of a PGM being present. The z-axis on the wireframe is scaled from $0-1$. The other two axes are scaled from min to max.

\section{OUT OF SAMPLE PREDICTIONS}

Despite the support for the Accountability Avoidance Model in combination with civil violence, our flexible model might be over-fitting idiosyncrasies in the sample data. Therefore, we use out-of-sample validation to further support our argument that it is not only domestic disorder and logistical concerns that motivate governments to use informal armed groups, but 
also a logic of avoiding accountability. We first refit each model to the sample from 1981 to 2001. Then we take the estimated coefficients and calculate predicted probabilities for the data from 2002 to 2005 . If we are overfitting the sample data, the out-of-sample fit should be relatively poor. Figure 4 presents out-of-sample separation plots (Greenhill, Ward, and Sacks 2011), which order the predicted probabilities from low to high values as one moves from left to right. For each prediction, a vertical red line is drawn if government-militia ties were present in the observed out-of-sample data, and a white line if not. If the model separated the observations of these ties perfectly, then the right side of the plot would be red and the left side white. A poor fitting model would have red lines towards the left of the panel, which represent observations with very low predicted probabilities from the model (since they are sorted on the left) but actual observed values where ties were in fact present (hence the red vertical line).

The out-of-sample separation plot for the Disorder Model is relatively poor. It predicts informal government-militias linkages where none are observed in the data, indicated by the red lines towards the left of the plot area, although there is an increasing pattern of observed linkages as one moves towards the higher predicted probabilities on the right. In comparison, the out-ofsample separation plot for model 3 from Table 2, which includes the Accountability Avoidance variables and models the potential nonlinear relationships, is visibly improved. There is considerable white space on the left, representing no informal government-militia relationships where the model does not expect them to be and an increasing density of red observed relationships on the right, where the model predicts a higher density of informal militia ties. The Brier scores for each model confirm the visual impression. The Disorder Model has a Brier score of .10 , the model adding our measures and nonlinearities a Brier score of .03 , where smaller scores imply a better fit between the predictions and the data. The Brier score for the combined 
Accountability Avoidance Model is akin to predicting an informal government relationship with a militia with a probability of .82 and it then occurring. ${ }^{30}$ This is helpful evidence that our inclusion of additional variables and flexible functional forms did not over-fit the sample and forecasts well out-of-sample.

\section{Baseline Model}

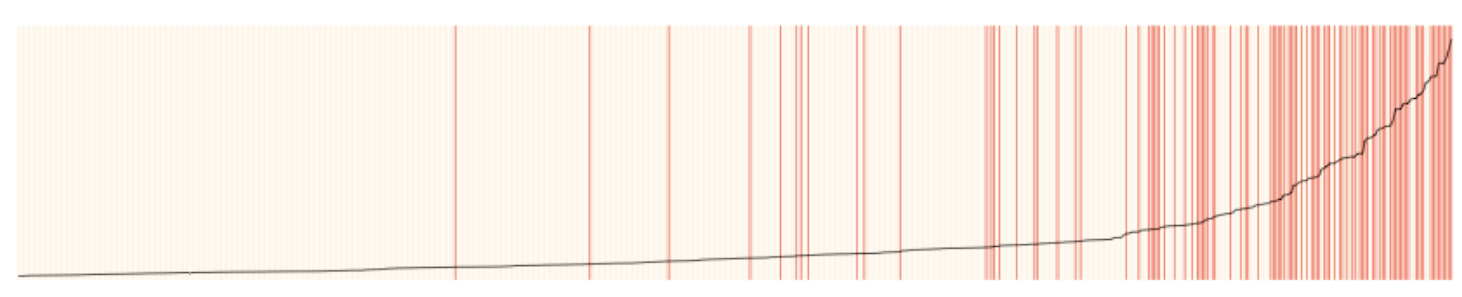

\section{With Accountability Avoidance Measures and 2-D Smooth}

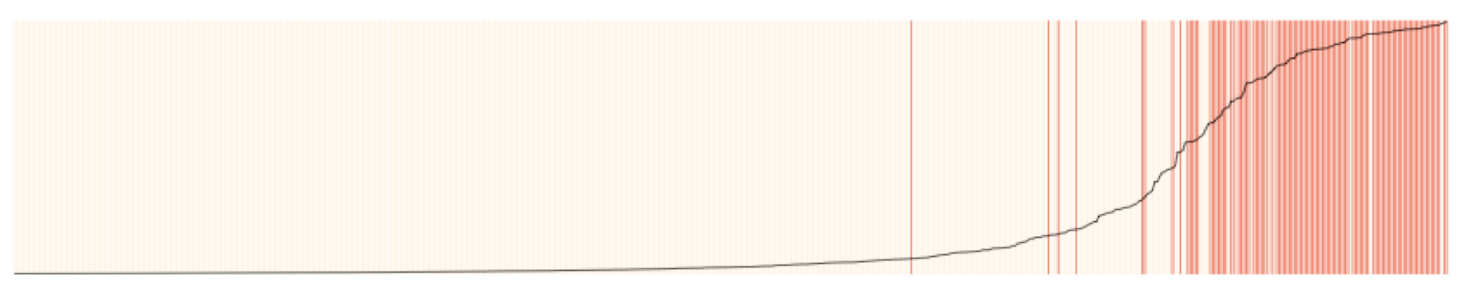

FIGURE 4. Separation Plots Comparing the Predicted Probability of Informal Government-Militia Ties with Out-of-Sample Observations Across Two Models.

Note: The baseline model includes only the disorder variables, population, and GDP. The added model includes the variables in model 3 of Table 2. The models are fitted to data from 1981 to 2001 and validated on data after 2001.

\footnotetext{
${ }^{30}$ The Brier score equals the mean of the squared distance between the predicted probability and the observed value.
} 
We also conducted several robustness tests that are detailed in the supporting information. To exclude the possibility that armed conflict drives our results, we excluded all countries from our sample with a civil war at any point during our observed time period. This did not alter our inferences, as there continued to be support for the hypothesized relationship between aid from democracies and informal government-militia ties, as well as between these links and weak democracy. Next, we included fixed effects for region, year, and then both region and year to the specification in Model 2, Table 1 as unobserved heterogeneity that might be correlated with our independent variables might drive our results. Again our inferences across the models remain robust. We also reran each model using only lagged independent variables and arrived at the same inference with slightly larger coefficients in absolute value. ${ }^{31}$ This leaves us with a picture of where governments are likely to collaborate with informal armed groups. It is not simply that governments use militias during civil disorder, but unofficial ties to militias appear in places where governments have some chance of avoiding accountability for their actions and an incentive to do so.

\section{Conclusion}

We have argued that there are political as well as logistical incentives to delegate violence to informal armed groups. Our theoretical framework specifies the conditions under which governments are most likely to try to avoid accountability by collaborating with militias. While research has shown that governments avoid using repression when they expect to be punished for the violence, we argue that governments not only decide between using or not using violence.

\footnotetext{
${ }^{31}$ We also controlled for an alternative measure of ethnic fractionalization using the Ethnic Power Relations data. Our inferences continued to be robust to these changes.
} 
Governments can also choose to shift responsibility for repression. Having ties to informal militias provides governments with plausible deniability for the violence they might commit.

Clearly not all governments use militias. Loss of control or 'shirking' in this policy area has risks. Countries that expect to be punished for using violence and that are better placed to hide their ties with militias are most likely to use these groups. We measure the chance of getting away with delegating to militias with distance from the nearest democracy, as well as the absence of media access. The accountability cost for repression is operationalized with dependence on foreign aid from democracies. Our results show that governments that receive most aid from democratic donors and are also furthest away from democracies are most likely to have ties with militias. Using out-of-sample predictions further supports our finding that domestic disorder and civil war are only part of the reason for government-militias ties. While governments are more likely to establish links with informal armed groups during times of domestic conflict, governments' incentives to avoid accountability for violence also play a crucial role.

The policy implications for the international community are twofold. First, this study highlights the need to anticipate unintended consequences of threatening to punish states for repression. Weak democracies appear to be using informal militias to avoid accountability for repression. Other work suggests that these informal ties to militias may make violence and human rights abuses worse (Mitchell, Carey, and Butler 2014). Second, to prevent government officials sheltering behind deniability claims, the government should be reminded of the responsibility to ensure compliance with international standards. Responsibility should be placed on the donor community to adopt as an explicit criterion in aid decisions a thorough assessment of the recipient's security sector and the use or past use of militias. 
More broadly, our study contributes a theoretically motivated global analysis of a neglected element of the security sector. As others have suggested, the monopoly of violence within a states is not a given (Ahram 2011a, 2011b; Staniland forthcoming). Under some circumstances states may prefer a majority position.

This perspective raises questions for future research. What accounts for the supply of personnel for these groups and what role do different actors, such as parties, unions and regional power bases, play in inducing or encouraging the formation of informal militias? What effect do these groups have on the outcome of conflicts and on civilian welfare? What theoretically meaningful distinctions should be used to further disaggregate these groups? Finally, it is possible that further work on the incentives for informal militias can help solve remaining puzzles in understanding the contribution of militias to civilian welfare and regime security, as brought to the forefront in several contributions to this special issue (Cohen and Nordas forthcoming; Stanton forthcoming; Ahram 2011b). 


\section{References}

Ahram, Ariel I. 2011a. "Origins and Persistence of State-Sponsored Militias: Path Dependent Processes in Third World Military Development.” Journal of Strategic Studies 34 (4): 531 56

Ahram, Ariel I. 2011b. Proxy Warriors: The Rise and Fall of State-sponsored Militias. Stanford: Stanford Security Studies.

Alvarez, Alex. 2006. "Militias and Genocide." War Crimes, Genocide, \& Crimes against Humanity 2: 1-33.

Banks, Arthur S. 2008. "Cross-national Time-Series Data Archive User's Manual." http://www.databanks.sitehosting.net/.

Banks, Jeffrey S, and Barry R. Weingast. 1992. "The Political Control of Bureaucracies under Asymmetric Information." American Journal of Political Science 36 (2): 509-24.

Bates, Robert. 2008. When Things Fell Apart: State Failure in Late-Century Africa. Cambridge: Cambridge University Press.

Bohara, Alok, Neil J. Mitchell, Mani Nepal, and Nejem Raheem. 2008. "Human Rights Violations, Corruption, and the Policy of Repression." Policy Studies Journal 36: 1-18.

Brysk, Alison. 2014. "Perpetrators of "Private Wrongs": Non-state Actors, Violence Against Women, and Responsiveness to Transnational Human Rights Campaigns” International Studies Association Annual Meeting Toronto March 26-29.

Bueno de Mesquita, Bruce, George W. Downs, Alastair Smith, and Feryal Marie Cherif. 2005. “Thinking Inside the Box: A Closer Look at Democracy and Human Rights." International Studies Quarterly 49 (3): 439-457.

Campbell, Bruce B, and Arthur D. Brenner (eds). 2000. Death Squads in Global Perspective: 
Murder with Deniability. London: Palgrave MacMillan.

Carey, Sabine C, Neil J. Mitchell, and Will Lowe. 2013. "States, the Security Sector, and the Monopoly of Violence: A New Database on Pro-Government Militias." Journal of Peace Research 50 (2): 249-258.

Cingranelli, David, and Mikhail Filippov. 2010. "Electoral Rules and Incentives to Protect Human Rights.” Journal of Politics 72 (1): 243-257.

Cohen, Stanley. 2001. States of Denial: Knowing About Atrocities and Suffering. London: Polity Press.

Cohen, Dara K., and Ragnhild Nordas. Forthcoming. "Why Do Militias Abuse Civilians? Evidence from Recent Armed Conflicts (1989-2009).” Journal of Conflict Research 0 (0).

Colaresi, Michael P. 2014. Democracy Declassified: The Secrecy Dilemma in National Security. Oxford: Oxford University Press.

Conrad, Courtenay R., and Will H. Moore. "What Stops Torture?” American Journal of Political Science 54 (2): 459-476.

Cribb, Robert. 2001. “Genocide in Indonesia, 1965-1966." Journal of Genocide Research 3 (2): 219-39.

Davenport, Christian, and David A. Armstrong. 2004. "Democracy and the Violation of Human Rights: A Statistical Analysis from 1976-1996.” American Journal of Political Science 48 (3): 538-554.

Donahue, John D, and Richard J. J. Zeckhauser. 2011. Collaborative Governance: Private Roles for Public Goals in Turbulent Times. Princeton: Princeton University Press.

Downes, Alexander B. 2006. "Desperate Times, Desperate Measures: The Causes of Civilian Victimization in War.” International Security 30: 170. 
Eck, Kristine. Forthcoming. "Repression by Proxy: How Military Purges and Insurgency Impact on the Delegation of Coercion." Journal of Conflict Research $0(0)$.

Fearon, James D, and David Laitin. 2003. "Ethnicity, Insurgency, and Civil War." American Political Science Review 97 (1): 75-90.

Fiorina, Morris P. 1985. "Group Concentration and Delegation of Legislative Authority." In Regulatory Policy and the Social Sciences, ed. Roger G. Noll. Berkeley: University of California Press, $175-97$.

Gleditsch, Nils Petter, Peter Wallensteen, Mikael Eriksson, Margareta Sollenberg, and Håvard Strand. 2002. “Armed Conflict 1946-2001: A New Dataset.” Journal of Peace Research 39 (5): 615-37.

Grant, Ruth W., and Robert O. Keoohane. 2005. "Accountability and Abuses of Power in World Politics." American Political Science Review 99 (1): 28-43.

Greenhill, Brian, Michael D. Ward, and Audrey Sacks. 2011. "The Separation Plot: A New Visual Method for Evaluating the Fit of Binary Models." American Journal of Political Science 55 (4): 991-1002.

International Criminal Court Press Release 2008, July 14. http://www.icccpi.int/en_menus/icc/situations\%20and\%20cases/situations/situation\%20icc\%200205/press \%20releases/Pages/a.aspx

Jentzsch, Corinna, Stathis Kalyvas, and Livia Isabelle Schubiger. Forthcoming. "Militias in Civil Wars: An Emerging Research Agenda." Journal of Conflict Resolution 0 (0).

Judah, Tim 2014. “The Battle for Ukraine.” New York Review of Books July 10: 76-80

Kalyvas, Stathis. 2008. "Ethnic Defection in Civil War." Comparative Political Studies 41 (8): 1043-68. 
Kirschke, Linda. 2000. "Informal Repression, Zero-Sum Politics and Late Third Wave Transitions." Journal of Modern African Studies 38 (3): 383-405.

Landman, Todd. 2005. Protecting Human Rights: A Comparative Study. Washington DC: Georgetown University Press.

Levitsky, Steven, and Lucan A. Way. 2010. Competitive Authoritarianism: Hybrid Regimes After the Cold War. Cambridge: Cambridge University Press.

Marshall, Monty G, Keith Jaggers, and Ted Robert Gurr. 2010. “The Polity IV Project.” Center for Systemic Peace, www.systemicpeace.org/polity/polity4.htm.

Mazzei, Julie. 2009. Death Squads or Self-Defense Forces: How Paramilitary Groups Emerge and Challenge Democracy in Latin America. Chapel Hill: University of North Carolina.

Meo, Nick. 2008. "Sudanese Government Backed Darfur Attacks, says Janjaweed Commander." The Telegraph, 12 July.

Mitchell, Neil J. 2004. Agents of Atrocity: Leaders, Followers and Human Rights Violations in Civil Wars. New York: Palgrave Macmillan.

Mitchell, Neil J., and Sabine C. Carey. 2013. "Pro-Government Militias Database (PGMD) Codebook." University of Mannheim, accessed at http://www.sowi.unimannheim.de/militias/?page id=15

Mitchell, Neil J., Sabine C. Carey, and Christopher K. Butler. 2014. “The Impact of ProGovernment Militias on Human Rights Violations.” International Interactions 40 (5): 812$\underline{836 .}$

Mitnick, Barry M. 1980. The Political Economy of Regulation. New York: Columbia University Press.

Nielsen, Richard A. 2013. "Rewarding Human Rights? Selective Aid Sanctions against 
Repressive States.” International Studies Quarterly 57 (4): 791-803.

Norris, Pippa. 2008. Driving Democracy. Cambridge: Cambridge University Press.

Norris, Pippa. 2009. Codebook for Democracy Time Series Dataset. Unpublished Manuscript.

Peter, To A. 2013. "Poll Shows Erdogan's Popularity has taken a Hit." Christian Science Monitor, 18 June.

Pomfret, John. 1994. "Serbia Suspected of Aiding Bosnian Allies." The Washington Post, 9 December.

Risse, Thomas, Stephen C. Ropp, and Kathryn Sikkink. 1999. The Power of Human Rights: International Norms and Domestic Change. Cambridge: Cambridge University Press.

Roessler, Philip G. 2005. "Donor-Induced Democratization and the Privatization of State Violence in Kenya and Rwanda." Comparative Politics 37 (2): 207-27.

Simmons, Beth. 2009. Mobilizing for Human Rights. Cambridge University Press.

Singer, J. David. 1987. "Reconstructing the Correlates of War Dataset on Material Capabilities of States, 1816-1985." International Interactions 14 (2): 115-32.

Staniland, Paul. 2012. "Between a Rock and a Hard Place: Insurgent Fratricide, Ethnic Defection, and the Rise of Pro-State Paramilitaries." Journal of Conflict Resolution 56 (1): $\underline{16-40 .}$

Staniland, Paul. Forthcoming. "The State and the Monopoly of Violence." Journal of Conflict Resolution 0 (0).

Stanley, William D. 1996. The Protection Racket State: Elite Politics, Military Extortion, and Civil War in El Salvador. Philadelphia: Temple University Press.

Stanton, Jessica. Forthcoming. "Regulating Militias: Governments, Paramilitaries, and Civilian Targeting in Civil War." Journal of Conflict Resolution 0 (0). 
United Nations 2013 Commission of Inquiry 18 February.

http://www.ohchr.org/EN/NewsEvents/Pages/DisplayNews.aspx?NewsID=13003\&LangID=E

Vasagar, Jeevan. 2004. "Inside the Janjaweed: How One Man Escaped Ethnic Cleansing in Darfur." The Observers, 31 July.

Weidmann, Nils B, and Kristian Skrede Gleditsch. 2010. "Mapping and Measuring Country Shapes." The R Journal 2 (1): 18-24.

Weidmann, Nils B, Doreen Kuse, and Kristian Skrede Gleditsch. 2010. "The Geography of the International System: The CShapes Dataset.” International Interactions 36 (1): 86-106.

Williamson, Oliver E. 1999. "Public and Private Bureaucracies: A Transaction Cost Economics Perspective." Journal of Law, Economics, \& Organizations 15 (1): 306-42. 